\title{
Model of Teaching "Participatory Observation in Islamic Education" to Improve Religious and Social Characters of University Students: a Preliminary Research
}

\author{
Ahmad Munjin Nasih, Achmad Sultoni \\ Department of Arabic Literature, Faculty of Letters \\ Universitas Negeri Malang \\ Malang, Indonesia \\ munjin.nasih.fs@um.ac.id
}

\author{
Ah. Zakki Fuad \\ Department of Islamic Education and Teacher Training. \\ The State of Islamic University Sunan Ampel \\ Surabaya, Indonesia
}

\begin{abstract}
The implementation of Islamic education in Indonesian universities is criticized to be cognitive oriented, conventional, and to give less attention to moral issues of students. The research aimed to describe a teaching model that improves students' religious and social characters called "participatory observation in Islamic Education Program" and to assess the validity, practicability and effectiveness of the model. By using modified steps of Plomp's research and development, the research produced the syntax of the teaching model consisting of seven steps, namely a) orientation, b) identification and finding the "learning partner" c) initial observation, d) observation, d) giving gift, e) reflection, f) making report, and g) presentation. Being examined by teaching experts, lecturers of Islamic Education, and students, the model of teaching is classified as valid, practicable, and effective in developing religious and social characters of students.
\end{abstract}

Keywords-model of teaching, religious and social character, Islamic Education

\section{INTRODUCTION}

Education is a medium for improving the quality of human resources so that people could experience the advancement in various areas of their lives. In the context of Indonesia, it is reflected in the Constitution of National Education System [1], Chapter II Article 3. It mentions that all national education units function to develop students' skills and shape their mindset as well as the civilization of the nation that has a good dignity in order for enlightening the life of the nation. While the goal of national education is the development of students' potentials so that they become individuals who have faith and piety to the One Almighty God, who have noble attitudes, who are healthy, enlightened, capable, creative, independent, and who can become democratic and responsible citizens [1]. In short, there are three aspects that need to be developed according to the [1], namely cognitive, psychomotor, and affective aspects.

In term of developing students' affective and moral characters, religion education becomes the main media. The Governmental Regulation on Religious Education [2] mentioned that "religious education has the function of shaping
Indonesian individuals that have a strong faith and piety upon the Almighty God and noble attitudes, and who are able to keep peaceful and orderly relationships among them with either similar or different religions". The importance of religious education for the living of the nation can be seen when the government obliges the religious education to be given from the Primary until Tertiary Level as a specific subject, and all students are required to learn it [2].

Nevertheless, attitude or character education for students in formal educational institutions through the teaching of religion faces various problems that cause the unachieved result of its intended functions. The failure is seen in the form of the occurrence of various issues in morality and character among the students such as premarital sex [3], [4], drugs abuse [5], brawl, and even murder [6]. Especially among university students, there are a lot of cases where students practice a hedonism lifestyle, such as hanging out in café, drug abuse, alcohol drinking, enjoying striptease dance, and having premarital sex [7]-[9]

According to [10], the occurrence of moral problems mentioned above among Moslem teenagers in Indonesia is, among others, due to the incompatible approach of the Islamic Education Course (in Indonesia, the subject of study is named Pendidikan Agama Islam (Islamic Education Program), which is shortened as PAI) with its objectives. It is also because the teaching model of PAI tends to be conventional and focus more on developing students' cognitive aspect. Similar to [11] said that moral problems among students are due to the teaching of PAI that is not designed to internalize the Islamic values to the students. Also, the teaching method for the PAI is focusing more on the traditional and conventional method and the development of cognitive aspect as well as the practical worship and ritual. On the other hand, Hidayat [12] criticized the teaching of PAI that tends to teach religion to students without teaching how the students should practice religious values in their lives.

In brief, problems in Islamic Education for university level come from the ways (model, method, design) of teaching that are cognitive oriented, conventional, traditional, and give less attention to affective domain, whereas at the same time many 
students still misbehave. Considering the problems, it is urgent to create innovation in teaching Islamic Education that is oriented on character building. The innovation can be made in the areas of teaching method, media, strategy, evaluation, to a more complex one such as teaching model.

Several researchers have done this research about teaching model to develop the characters of the student. In the research entitled "Development of Religious-Humanist Teaching Model in Character Education in Primary Education" [13], developed the teaching model to internalize the religious-humanist values into the students through all the subjects they take. Meanwhile in his research, Hanifudin [14] developed a teaching model of Islam Education based on Multiple Intelligence for Junior High School in order to improve the compound knowledge of the students so that they have the character, attitude, good personality that is in harmony, and balance. While the research in developing the teaching model for Islamic Education in improving religious and social characters of students are not yet to be found.

Based on the background mentioned and the framework above, research on innovation in the teaching model of Islamic Education in improving students' religious as well as social characters of students is seen to be vital and strategic. In relation to such matter, this preliminary research attempts to develop the teaching model of Islamic Education to improve religious and social characters of students. A teaching model is a pattern or a plan, which can be used to shape a curriculum of a course, to select the instructional materials, and to guide a teacher's classroom actions [15]. It guides teachers during the learning activities systematically and effectively based on the learning objective, students' conditions, available time, and learning media.

The model of teaching developed in this research is called as "Participatory Observation in Islamic Education" because it requires students to observe and participate in a certain activity designed as a part of Islamic teaching (in Indonesia, the subject is called as PAI). This teaching model is inspired by the TV show of a private channel entitled "Andai Aku Menjadi" or in English "If I were". The aims of this preliminary research is to describe the syntax of "Participatory Observation in PAI" and to asses the validity, practicability and effectiveness of the syntax. The result of this research is expected to contribute significantly in improving the quality of teaching PAI in tertiary education so that it may produce students with good characters and morality.

\section{RESEARCH METHOD}

In order to create the teaching model of "Participatory Observation in PAI", this research used the steps of modified Plomp's research and development. The Plomp model [16] consists of six phases, namely preliminary investigation, design, realization/construction, testing, evaluation and revision, and implementation. This research only uses the first five phases because of the limited time and expense. The Plomp's version of research and development was chosen because it was designed to be used for educational field. The phases were relatively simple and still could produce a qualified product.
Prelimenary investigation phase consisted of analyzing the needs, literary review, and the small-scale field research in Universitas Negeri Malang (UM). Based on the result of the first phase, the design of the "Participatory Observation in PAI" teaching model was created. The teaching model contained of syntax or steps of teaching. Afterwards, in the realization/construction phase, the sintax of teaching model was created based on the design that was made beforehand. The result is in the form of prototype I of the teaching model. Prototype I was then evaluated and revised so that it becomes the qualified teaching model. These steps are done through:

The validation or evaluation from the expert (Dr. Sulton, M.Pd, lecturer of Faculty of Education and head of institution of development of learning and education of Universitas Negeri Malang) on the appropriateness of the teaching model for the learning theory and the harmony among the syntax components. The instrument used in validation was the validation/evaluation sheets filled with qualitative essay questions.

The evaluation that should be performed by the practitioners/lecturers of Islamic Education was done by two lecturers of Islamic Education in UM by conducting a theoretical review upon the practicality of the prototype 1 . The instrument used to assess was the result of qualitative evaluation sheet.

The result or the validation from the expert of teaching and lecturer of Islamic Education became the standard in revising the prototype, which would be tested in classrooms. The research design used was one-shot case study. The subjects of the research were the students of UM, i.e., two classes from the Faculty of Economics and one class from the Faculty of Engineering who took Islamic Education course in their odd semester of 2016/2017 academic year. During the research implementation, the students evaluated the effectiveness of the teaching model and gave responses to the teaching model. The instrument chosen in this research was in the form of scale of an attitude scale or a "rating scale" and qualitative descriptions.

The results of the test were then analyzed and became the base of the prototype revision to produce the final product in the form of a teaching model. The qualitative data collected was analyzed via descriptive qualitative analysis while the quantitative data - gained from the scale of student attitude using the rating scale- was analyzed by quantitative analysis.

\section{FINDINGS}

\section{A. Validation of experts and practitioners}

Through the phases of prelimenary investigation, design, and construction, the research produced prototype of the teaching model. The prototype is a syntax containing eight steps of teaching. Table 1 shows the details of the syntax. 
TABLE I. PROTOTYPE OF SYNTAX OF TEACHING MODEL

\begin{tabular}{|l|l|l|}
\hline No & \multicolumn{1}{|c|}{ Syntax the } & \multicolumn{1}{c|}{ Description of activities } \\
\hline 1 & $\begin{array}{l}\text { Delivering } \\
\text { assignment } \\
\text { observation and the } \\
\text { rule of practice }\end{array}$ & $\begin{array}{l}\text { The lecturer explains the rules consisting of: } \\
\text { Goal of activity } \\
\text { Pairing the students } \\
\text { Procedure } \\
\text { Time allocation for the activity }\end{array}$ \\
\hline 2 & $\begin{array}{l}\text { Finding a learning } \\
\text { partner }\end{array}$ & $\begin{array}{l}\text { Students autonomously find their learning } \\
\text { partners around the campus or their houses }\end{array}$ \\
\hline 3 & Initial observation & $\begin{array}{l}\text { Students introduce themselves and their } \\
\text { objectives to their learning partner, and } \\
\text { negotiate time and procedure of the } \\
\text { participatory observation }\end{array}$ \\
\hline 4 & $\begin{array}{l}\text { Performing } \\
\text { participatory } \\
\text { observation }\end{array}$ & $\begin{array}{l}\text { Students act as if they are the learning } \\
\text { partners (perform the activities of the } \\
\text { learning partner), make informal interview } \\
\text { about daily activities of their learning } \\
\text { partners, visit their learning partners' houses, } \\
\text { and document their activities }\end{array}$ \\
\hline 5 & $\begin{array}{l}\text { Preparing and giving a } \\
\text { presentation }\end{array}$ & $\begin{array}{l}\text { Students thank their learning partners and } \\
\text { give them presents }\end{array}$ \\
\hline 7 & Reflection, reporting, \\
and presentation & $\begin{array}{l}\text { Students make reflections of the completed } \\
\text { activities, make reports, then present the } \\
\text { reports in the classroom }\end{array}$ \\
\hline 8 & Reinforcement & $\begin{array}{l}\text { The lecturer gives some responses to } \\
\text { reinforce positive reflections and reports of } \\
\text { the students }\end{array}$ \\
\hline $\begin{array}{l}\text { Evaluation lecturer evaluates students reports, } \\
\text { performance, and attitude }\end{array}$ \\
\hline 6
\end{tabular}

Before it was actually tested to the students, the prototype of the teaching model was validated by the experts and practitioners using an open questionnaire. The teaching experts evaluated the questionnaire in terms of the validity of the teaching model for the learning materials and consistency among the steps in the syntax, whereas the practitioners of Islamic Education were requested to give responses to the questionnaire regarding the practicability of the steps in the teaching model syntax related to reality of teaching. Here are results of validation mentioned in details.

\section{1) Validation from Teaching Experts}

According to the teaching experts, the syntax of the teaching model in Table 1, contains teaching procedure or steps that are systematic, in order, and easy to understznd. Besides, the activities for the students in the model are also clear. Yet, in term of determining the education partner, the teaching experts argued that the criteria of the profession for an education partner as the observation target needs to be more specific in order to ease the students in finding the "learning partner" and the effectiveness of achieving the goal of the teaching model. To sum up, the teaching experts mentioned that the syntax of the teaching model is categorized as very good.

\section{2) Validation from Practitioners}

Dr. Lilik Nur Kholidah, S.Pd. M.Pd.I, an Islamic Education lecturer who was asked to validate the teaching model mentioned that this model is applicable for Islamic teaching, both from the perspective of lecturers as well as students. However, she suggested that the role of lecturers and students in each step of the teaching model needs to be described in a more detailed way to prevent any mistakes or deviation in applying this model.
TABLE II. RESUlT OF STUDENT ATTITUDE SCALE

\begin{tabular}{|l|l|l|}
\hline \multicolumn{1}{|c|}{ Item } & Score & \multicolumn{1}{c|}{ Note } \\
\hline Highest score of the students & 100 & One person \\
\hline Lowest score of the students & 76 & One person \\
\hline Total score & 5402 & Score of all students \\
\hline Average score & 88,55 & \\
\hline Middle score/median & 65 & \\
\hline Number of participant & 61 person \\
\hline
\end{tabular}

Laily Maziyah, S.Pd., M.Pd., lecturer of PAI UM, also argues that the steps or syntax in the teaching model is seen as practical and applicable. In addition, the validator advised that the choice of learning partner should be broader in term of its scope, that is not only from the profession that is seen as low by the society and making less income, but also from other professions that allow the students to learn positive characters and attitude. The choice, according to her, must be adjusted with the social, economic, and cultural backgrounds of the students. The next advice was that the model of teaching needs to come along with the guidance for the evaluation to evaluate students.

\section{B. Effectiveness of Teaching Model and Response from the Students}

The data that will be explained in this section is the data related to the effectiveness of the model and the response of the students to the teaching model. The scoring upon the effectiveness of the teaching model was done upon 61 students who were randomly picked through an attitude scale in form "rating scale" with four choices that describe students' positions in the aspects of social and religious attitude stated in 26 statements. Some of the items presented to the students are designed to be positive and negative to maintain the validity of the scale. In each item, the lowest score is 1 , and the highest score is 4 . The maximum score of the scale is $4 \times 26=104$, while the lowest one is $1 \times 26=26$, and the median is 65 . Table 2 presents the result of the attitude scale.

Based on the result of the attitude scale, the lowest score of the students was 76. Compared to the median score of the questionnaire, i.e. 65, then the lowest score achieved by the students is still above the average or in the middle upper class. While, the highest score gained by the students was 100 , this score is the score that is close to the highest score of the questionnaire, namely 104 . While the average score gained by the students was 88.5 and it is classified as high. Hence, based on the result of the attitude scale, the "Participatory Observation in Islamic Education" teaching model is effective for developing the social and religious character of students.

While, the response of the students to the teaching model was collected in the form of an open questionnaire that was divided into three aspects, namely the strength of the model, weakness of the model, and the recommendation in using the teaching model. The summary of the responses from the 61 students to the teaching model is given as follow.

\section{1) The strength of the teaching model}

Students mentioned four advantages of the teaching model, i.e. the teaching model is done outside the classroom, students can live and feel the struggle and limitation of their education partners, students gain various values of morality, such as to be 
grateful, patient, empathic, independent, and respectful, and the students are triggered to make a self-evaluation, and correct their bad habits.

\section{2) The weakness of the teaching model}

In this aspect, students showed many weakness of the model, which mainly relate to the technical aspects of its implementation. In general, the model needs a relatively long time and involves many parties and activities. In terms of students, the problems include the group member that came from different departments, so that it needs some adjustment to the time of the activities, and the number of group members (only 2 persons) caused some hindrance.

Students found a lot of problems in term of "learning partners". Some students said that there is no guidance in interviewing their learning partners, and the criteria for the learning partners were not clear, so they had difficulties in finding appropriate learning partners. Other students felt it is hard to adjust their time with their learning partners. Other problems are the locations of their learning partners that are far so that it costed much money, and some learning partners refused to allow the students to observe their life.

\section{3) Recommendation for the teaching model}

In order to make the teaching model better, students gave some suggestions. First, the lecturers should deliver the instructions of the participatory observation in the first meeting in the beginning of the semester and explain the rules and provide detailed guidance so that students can do it well. Second, the lecturers need to help their students to select their learning partners so that the choice is not limited to one particular profession only. Third, lecturers need to provide the students with a formal letter to be given to their learning partners that explains the purpose of their observation. Fourth, there should be a follow-up activity for the participatory observation teaching model. Lastly, the teaching model should be applied to all students who take the Islamic Education subject, for not only it is fun, but it also has a lot of benefits.

The result of validation done by the expert and lecturer who mentioned that the teaching model is valid and applicable was supported by the result of an attitude scale of the students that indicated the effectiveness of the teaching model in improving the religious and social characters of the students. It indicated that the teaching model of "Participatory Observation of Islamic Education" could be used in the teaching of Islamic Education Program in ttertiary education level (university).

Besides, the suggestion of the experts and lecturers and the response of the students who experienced the model firsthand seemed to be completing each other. The experts and practitioners gave many theoretical and important suggestions for revising the validity and practicality of the teaching model, while based on the given suggestions, the students mostly focused on the technicalities of the "Participatory Observation in Islamic Education" teaching model.

Although there are numbers of suggestion for the teaching model revision, it does not indicate that the teaching model is not qualified. It can be seen from the response of the students, which mentioned that the teaching model has a lot of benefits and must be applied in teaching Islamic Education in the university level. Therefore, the suggestions made for the revisions to the teaching model is regarded as an attempt to improve the teaching model so that it becomes more valid, practical, and effective for achieving the goals of Islamic teaching.

\section{PRODUCT REVISION}

Based on the advices from the experts of teaching, the Islamic Education lecturers should act as practitioners as well as students towards the prototype of the model, some revisions were made to the teaching model. The revised aspects include:

- Criteria of the learning partners should be more detail and specific, and they should cover various professions that enable students to obtain better religious and social education.

- The activities of the lecturers and students in implementing the teaching model should be described more specifically.

- The grouping of the students should be designed so that the students come from the same class.

- The time of practicing the Participatory Observation is designed to be mentioned in the early meetings of the semester and is collected nearly at the end of semester.

- The technical guide for the Participatory Observation is made in a complete set including the guidance in interview the learning partner and the formal letter for the observation.

After some revision was made to the teaching model, the final form of syntax of the "Participatory Observation in Islamic Education" teaching model to improve the social and religious characters of the students was produced. In Table 3, describes the final product of the teaching model in detail. The model is divided into three aspects: teaching phases, activities of lecturers, and activities of students.

\section{RESUlt AND DisCUSSION}

In the perspective of Joyce and Weill's classification of teaching model [17], "Participatory Observation in Islamic Education" teaching model is included in the category of social teaching model. It is because social interaction with members of society (in this model, the learning partners whose jobs are seen as low and difficult by the society) is the center of the "Participatory Observation in Islamic Education". In addition, students who learnt in groups found the values of patience, gratitude, empathy, and respect through their interactions with their learning partners. This process agrees with the description of the social teaching model according to Joyce and Weill of which function is improving social as well as personal life.

Besides, based on the perspective of the way students gain knowledge and improve their social and religious characters, the teaching model of "Participatory Observation in Islamic Education" uses the philosophy of constructivism. In the philosophy of constructivism, the students do not gain knowledge in the form of final product but they need to arrange it themselves through a learning process [18]. From the two 
TABLE III. FINAL PRODUCT OF THE TEACHING MODEL

\begin{tabular}{|c|c|c|}
\hline Phase of teaching & Lecturers & Students \\
\hline Orientation & $\begin{array}{l}\text { Delivering the assignment of the observation and the rules of } \\
\text { practice, which include: } \\
\text { Objective of the activities } \\
\text { Grouping of } 2 \text { members } \\
\text { Procedure } \\
\text { Time of practice (from the first meeting) and the due date of } \\
\text { collecting the report } \\
\text { Technical guides } \\
\text { Criteria of learning partner (various professions to learn } \\
\text { social and religious characters, especially those who are seen } \\
\text { to be low in social-economic aspects) }\end{array}$ & $\begin{array}{l}\text { Paying attention to the explanation of the lecturer, asking questions } \\
\text { about the assignment of the Participatory Observation that might be } \\
\text { unclear for the students. }\end{array}$ \\
\hline $\begin{array}{l}\text { Identification and the } \\
\text { search for the learning } \\
\text { partners }\end{array}$ & $\begin{array}{l}\text { Giving information to the students about various professions } \\
\text { that exist in the surrounding of the campus and other } \\
\text { locations which are deemed as suitable for the observation. }\end{array}$ & $\begin{array}{l}\text { Searching for learning partners nearby the campus or students' } \\
\text { houses, and consulting it to the lecturer, if necessary. }\end{array}$ \\
\hline Initial observation & $\begin{array}{l}\text { Giving solution to the students if there are some trouble with } \\
\text { the learning partner }\end{array}$ & $\begin{array}{l}\text { Getting in touch with the learning partners, delivering the intention, } \\
\text { asking the agreement of the partner, and dealing with the time and } \\
\text { setting on how to do the Participatory Observation teaching model }\end{array}$ \\
\hline $\begin{array}{l}\text { Participatory } \\
\text { Observation }\end{array}$ & $\begin{array}{l}\text { Giving solution to students if there are some hindrance during } \\
\text { the implementation of the Participatory Observation teaching } \\
\text { model }\end{array}$ & $\begin{array}{l}\text { Experiencing the profession of the learning partner } \\
\text { Interviewing the learning partner about his job, and expectation } \\
\text { Visiting the house of the learning partner and asking about his life } \\
\text { and family } \\
\text { Documenting all the activities by taking pictures and videos }\end{array}$ \\
\hline $\begin{array}{l}\text { Giving a present of } \\
\text { appreciation }\end{array}$ & $\begin{array}{l}\text { Giving advice to the students about what kind of present of } \\
\text { appreciation that is appropriate for their learning partners }\end{array}$ & $\begin{array}{l}\text { Expressing the gratitude to the learning partner and giving the } \\
\text { present to him/her }\end{array}$ \\
\hline Reflection & $\begin{array}{l}\text { Giving some inputs for the students about their activities by a } \\
\text { reflection, if it is necessary }\end{array}$ & $\begin{array}{l}\text { Having some reflection of what the students have done and relate it } \\
\text { to the their personal condition and daily habits }\end{array}$ \\
\hline Arrangement of report & $\begin{array}{l}\text { Reminding and guiding the students to make a report in the } \\
\text { form of a video }\end{array}$ & $\begin{array}{l}\text { Arranging the report of activities according to the guide from the } \\
\text { lecturer, which include: } \\
\text { Introduction (type of profession, location, personal identity of the } \\
\text { partner) } \\
\text { Detail of observation } \\
\text { Reflection } \\
\text { Response to observation } \\
\text { Closing }\end{array}$ \\
\hline $\begin{array}{l}\text { Presentation of the } \\
\text { report and reflection }\end{array}$ & $\begin{array}{l}\text { Guiding a presentation of the observation report } \\
\text { Giving responses toward the report in the form of an } \\
\text { evaluation to the observation and reinforcing the result of the } \\
\text { students' reflection } \\
\text { Drawing a conclusion as well as advice to do good deeds both } \\
\text { spiritually and socially }\end{array}$ & $\begin{array}{l}\text { Presenting the observation report via power point in the classroom } \\
\text { Delivering the reflection on the observation and relate that to their } \\
\text { personal lives }\end{array}$ \\
\hline
\end{tabular}

versions of the learning theory of constructivism, namely cognitive and social constructivism, this model of teaching uses the social constructivism [19] for, in this model, students gained knowledge and improved social and religious characters through their social interactions the in social life of the society.

The positive effect of teaching based on constructivism theory is that the students enjoy the learning process, easily remember information, and the process of gaining knowledge happens naturally and humanly [20]. Informal interview with a number of students who participated in "Participatory Observation in Islamic Education" indicates the confirmation upon this theory. After about two months of a final meeting of the Islamic Education teaching, three students who participated in "Participatory Observation in Islamic Education" in the previous semester admitted that they enjoyed the teaching model, learned social and religious characters, and consider it as the most memorable Islamic learning.

The "Participatory Observation in Islamic Education" teaching model comprises of three important aspects that connects with each other in determining the effectiveness of the model, including the interaction of students with their learning partners, students' activities in experiencing the jobs of their learning partner, and the reflection. When the students interact with their learning partners whose social and economic conditions are under the standard of society, they realized that they have better conditions. Such realization was stronger when the students felt the difficulty and the tiredness when experience the jobs of their learning partners. They felt the hardship of earning money, and they have to work hard to gain money. In this phase, students experienced and felt it directly and learned from the life of the society. In learning theory, what the students did is called as learning by doing. Such learning process is highly suggested by [21] who proposed educational institution to have a close relationship with the students' families and the society, so that students know and care about the society where they live.

After realizing the hardship experienced by the learning partners and how fortunate their conditions compared to them, students are supposed to do reflection upon their daily activities and habits by relating them to the lesson and awareness that they have just got. Thus, according to [22], students are expected to do analisys and interpretation in order to have better understanding upon themselves and the situations in their surroundings so they can perform better in the society. According to the data from the students who do reflection in 
the teaching model of "Participatory Observation in Islamic Education", almost all students said that they were less grateful, impatient, lack in management of time and money, and they are motivated to be a grateful and patient, and to be able to manage their time and money well.

\section{CONCLUSION}

The "Participatory Observation in Islamic Education" learning model should be used in teaching Islamic Education only once in one semester in order for the objective of this model to be achieved effectively. Besides, the use of the model that is more than once in one semester triggers boredom on the students, requires much energy, and spends a lot of time as well as money. Meanwhile, students also should allocate their time, energy, and money for other subjects.

The model of teaching is designed for teaching Islamic Education or PAI. However, with some modifications, the model can also be used for other subjects that focus to develop students' characters, morality, and spirituality, especially Religious Education. In case of its use in different level of education, the teaching model is able to be applied in Senior High School and Vocational High School (SMA or SMK) with some adaptation in the selection of learning partners and time. While the use of the teaching model in Junior High School (SMP) is not suggested since the students are too young to understand about works and activities to earn money.

This research and development is preliminary research, and has a number of limitations. Thereby, further research is necessary although it is categorized as valid, practical, and effective. The next research is supposed to involve more experts and lecturers to validate the teaching model. It includes students from universities with different characteristics. Besides, the instrument of validity should be quantitative in order to increase the accuracy. In case of the elements of the teaching model, further research should include the social system, principle of reaction, support system, and instructional and nurturant effect as an integral parts of the teaching model.

\section{REFERENCES}

[1] Constitution, "National Education System of Indonesia," 2003.

[2] Government Regulation of Republic of Indonesia, Religion Teaching and Religiosity Teaching. 2007.

[3] G. Gunawan, Perkembangan Peserta Didik. Malang: UMM Press, 2011.
[4] Depkes, "Situasi Kesehatan Reproduksi Remaja," www.depkes.go.id, 2016. [Online]. Available: www.depkes.go.id.

[5] A. Fiddy, "Narkoba di Kalangan Pelajar Makin Parah," nasional.sindonews.com, $2015 . \quad$ [Online]. Available: https://nasional.sindonews.com/read/906057/15/narkoba-di-kalanganpelajar-mahasiswa-makin-parah-1411908498.

[6] P. Fernando, "Dalam Sehari, 2 Siswa di Bekasi Tewas Akibat Tawuran Pelajar," http://news.liputan6.com, 2017. [Online]. Available: http://news.liputan6.com/read/2883727/dalam-sehari-2-siswa-dibekasi-tewas-akibat-tawuran-pelajar.

[7] N. Liata, "Gaya Hidup Gemerlap mahasiswa di Kota Yogyakarta," UIN Sunan Kalijaga, 2009.

[8] I. Wijayanto, Sex In The Kost. Yogyakarta: CV. Qalam, 2003.

[9] A.-R. Zulkifli, "Gaya Hidup Hedonisme Di Kalangan Mahasiswa Penerima Beasiswa Kaltim Cemerlang 2014 Di Fakultas Ilmu Sosial Dan Ilmu Politik Universitas Mulawarman," eJournal SosiatriSosiologi, vol. 4, no. 1, pp. 72-85, 2016.

[10] M. Muhaimin, Paradigma Pendidikan Islam. Bandung: PT Remaja Rosdakarya, 2002.

[11] M. A. Abdullah, Problem Epistemologis-Metodologis Pendidikan Islam. Yogyakarta: Pustaka Pelajar, 1998.

[12] K. Hidayat, "Preface" in Fuaduddin \& Cik Hasan Bisri (ed.). Dinamika Pemikiran Islam di Perguruan Tinggi. Jakarta: Logos Wacana Ilmu, 1999.

[13] A. G. Jumarudin and S. Siti, Partini, "'Pengembangan Model Pembelajaran Humanis Religius dalam Pendidikan Karakter di Sekolah Dasar," J. Pembang. Pendidik. Fondasi dan Apl., vol. 2, no. 2, pp. 114-117, 2014.

[14] H. Hanifudin, "Model pembelajaran PAI berbasis Multiple Intelligence (studi KTSP jenjang SMP).," IAIN Sunan Ampel Surabaya, 2011.

[15] B. Joyce and W. Marsha, Models of Teaching, Third Edit. New Jersey: Prentice Hall, 1980.

[16] T. Plomp, "Educational \& Training System Design," University of Twente, 1997.

[17] B. Joyce and W. Marsha, Models of Teaching, Fifth Edit. New Delhi: Prentice Hall, 2003.

[18] C. Bereiter, "Constructivism, socioculturalism, and Popper's world 3," Educ. Res., vol. 23, no. 7, pp. 21-23, 1994.

[19] R. J. Amineh and H. D. Asl, "Review of constructivism and social constructivism," J. Soc. Sci. Lit. Lang., vol. 1, no. 1, pp. 9-16, 2015.

[20] B. Bada and O. Steve, "Constructivism Learning Theory: A Paradigm for Teaching and Learning," IOSR J. Res. Method Educ., vol. 5, no. 6, pp. 66-70, 2015.

[21] J. Dewey, "Democracy and Education," Pennsylvania, 2001.

[22] J. Sandars, "The use of reflection in medical education: AMEE Guide No.44,” Med. Teach., vol. 31, no. 8, pp. 685-695, 2009 